\title{
Comparing techniques for determining steer diets in northern Chihuahuan Desert
}

\author{
MOHAMMAD M. MOFAREH, RELDON F. BECK, AND ALAN G. SCHNEBERGER
}

Authors are former graduate student (currently in Ministry of Agriculture and Water Resources, Yemen Republic); professor, Department of Animal and Range Sciences, New Mexico State University, Las Cruces, N.M. 88003-0003; and former graduate student (currently with N.M. Cattle Growers' Assoc., P.O. Box 7517, Albuquerque, N.M. 87107).

Abstract

Diets determined by bite count and microhistological analysis of esophageal extrusa and feces were compared for steers grazing on grass-shrublands in the northern Chihuahuan Desert. The study was conducted on the Chihuahuan Desert Rangeland Research Center near Las Cruces, New Mexico. The purpose was to determine the similarity of 3 dietary techniques on arid, heterogeneous rangeland. It was proposed that the number of bites of each species eaten was directly proportional to the weight eaten as determined by the 2 microhistological techniques. Samples of diets were collected in 4 seasons from 2 steers grazing in a continuous yearlong pasture and in seasonlong rotation pastures.

The 3 dietary techniques did not give similar $(P<0.10)$ estimates of the diets eaten by the steers. Mean similarity indices were highest (77\%) comparing diets from analysis of esophageal and fecal material. Lowest mean similarity indices $(57 \%)$ were from comparing diets from bite count and fecal analysis. Much of the discrepancy between techniques was because of different size plants being eaten and heterogeneity of plant distribution. An importance ranking of dietary species using the 3 techniques showed that the top 3 species comprised over $68 \%$ of the total diets. Any of the 3 techniques can be used to determine the common species in the diets which may be all that is necessary for some management and analysis needs.

Key Words: bite count, microhistological diet analysis, desert grassland.

One of the basic problems confronting the range scientist is an accurate assessment of the nutritive value and botanical composition of the grazing animal's diet. Knowledge of foods used by herbivores is basic to the management of their populations and environments (Galt et al. 1969, Ward 1970).

Techniques and the variations used for determining diets are discussed in Holechek et al. (1984). Three techniques commonly used are direct animal observations and analysis of either fecal materials or esophageal fistula extrusa. There are several studies where technique comparisons have been made, but only limited information is available on dietary comparisons of the 3 afore-

Research supported by the New Mexico Agr. Exp. Sta., Las Cruces, N.M Manuscript accepted 9 March 1996.
Resúmen

Los métodos del conteo del bocados y del análisis microhistologico de nuestras esofágicas y de heces, fueron comparados en novillos pastoreando en una comunidad de pastos $y$ arbustivas en el norte del Desierto Chihuahuense. El estudio se llevo a caho en el Centro de Investigaciones sobre Pastizales del Desierto Chihuahuense, cerca de Las Cruces, New Mexico, utilizando novillos y colectando muestras durante leas 4 estaciones del año. Se propuso que el numero de bocados de cada especie consumida era directamente proporcional al peso consumido.

Los resultados de los métodos fueron estadisticamente diferentes $(\mathbf{P}<0.10)$. Los indices de similaridad fueron mayores $(77 \%)$, cuando se comparó la dieta en muestras esofágicas con las de heces fecales. Los indices de similaridad fueron menores $(\mathbf{5 7} \%)$ cuando se comparo el conteo de bocados con el análisis microhistologico de heces. Mucha de la discrepancia de los datos obtenidos entre tratamientos, fue debida al diferente tamaño de las plantas consumidas y a la hetergenidad de la vegetación. Los 3 métodos mostraron que 3 especies constituyeron el $88 \%$ del total de la dieta, sugiriendo que cualesquiera de los métodos puede ser util para este tipo de estudios.

mentioned techniques, particularly in an arid environment, such as the northern Chihuahuan Desert.

The primary hypothesis tested in this study was that there are no differences in the estimates of the various species compositions in the diets among the 3 techniques. Direct observation (bite count or feeding time) is easy and simple and requires no equipment or surgery, but difficulty may arise in identification of plant species or situations where an animal may eat more than 1 species in a bite (Holechek et al. 1984). A problem with bite count method (Reppert 1960) is getting an estimate of weight consumed for each species. Regelin et al. (1974) simulated deer diets by hand plucking and found negligible differences between percentages of bites for a species and the percentage weight for the same species calculated by hand plucking. Getting actual weights for bites as proposed by Free et al. (1971) is difficult because of heterogeneity of the rangelands and the need for esophageal fistulated animals. Another potential source of error is developing an exchange ratio between bites of small plants and large plants as suggested by Sanders et al. (1980). Therefore, because of the difficulty in obtaining bite weights, number of bites of each species was assumed in this study to be directly pro- 
portional to weight intake of each species as proposed by Regelin et al. (1974).

The other 2 techniques studied also have problems. Both require extensive training in the use of microscopes, identification of plant fragments and careful preparation of microscopic slides (Holechek and Gross, 1982). Using esphogeal fistulated animals involves extra care of the animals. Vavra et al. (1978) and Coates et al. (1987) point out that diets from esophageal extrusa represent only a small portion of the total diet that animals select and eat from a pasture.

Diets determined from feces better represent the diets being selected from the whole pasture over a longer time period (Holechek et al. 1984). It also allows the estimation of diets without disturbing the animals. Problems associated with using fecal material to estimate diets are the different digestion rates of plant species, difficulty of identification due to greater degradation of cell wall material, and determining the age of fecal material sampled.

Holechek et al. (1984) ranked 13 dietary techniques by accuracy, precision, cost, and time. Microhistological analysis of feces and microhistological analyses of esophageal extrusa were ranked 2 and 4, respectively, while bite count with tame animals was ranked 7th. Vavra et al. (1978) mentioned that the esophageal method is often considered the standard. However, they also point out that analysis of fecal material to determine diets may be more important and practical when working with wildlife or where it is difficult to handle fistulated animals.

\section{Study Area}

This study was conducted on the New Mexico State University Chihuahuan Desert Rangeland Research Center located $38 \mathrm{~km}$ north of Las Cruces, N.M. Pastures in 2 grazing strategies were sampled, continuous yearlong grazing, and rotationally grazed pastures. The pastures varied in size from 500 ha to 1,250 ha. Each grazing strategy had a cow herd. Each of the 3 rotational pastures were grazed for an entire season al approximately the same time each year. Elevation of the study pastures varies from 1,330 to $1,348 \mathrm{~m}$. Climate of the area is arid, typified by very low relative humidity. Daily temperature fluctuations of $22^{\circ} \mathrm{C}$ are not uncommon. Average maximum temperature varies from a high of $36^{\circ} \mathrm{C}$ in June to a low of $13^{\circ} \mathrm{C}$ in January. The average wind velocity is $3.2 \mathrm{~km}$ per hour with highest wind movement occurring in April and May. Average annual precipitation is $23 \mathrm{~cm}$ (1930 to 1988) of which 52\% falls during the growing season of July through September. Annual rainfall was near 30\% above average in 1987 and 1988, preceding and during this study.

The general area is classified as semidesert grassland, composed primarily of herbaceous species with light to dense stands of shrubs scattered throughout the area. Vegetation is similar across all study pastures, but species differ in abundance in each part of the pastures. Major grass species are black grama (Bouteloua eriopoda [Torr.] Torr.), mesa dropseed (Sporobolus flexuosus [Thurb] Rydb.), three-awns (Aristida spp.) and fluffgrass (Erioneuron puchellum [H.B.K.] Tateoka). Many forb spccics are common on the pastures. Primary shrubs include mesquite (Prosopis glandulosa Torr.), snakeweed (Gutierrezia sarothrae [Pursh] Britt. \& Rusby), soaptree yucca (Yucca elata Engelm.), longleaf ephedra (Ephedra trifurca Torr.) and fourwing saltbush (Atriplex canescens [Pursh] Nutt.). Surface soil layers vary from loamy fine sands to sandy loams, with depths to caliche varying from 10 to $100 \mathrm{~cm}$ (Beck 1978). Soils have almost no humus or organic matter and there is little change in texture between surface soil and subsoil.

\section{Materials and Methods}

\section{Diet Sampling}

Two yearling crossbred steers (Brangus $\times$ Hereford) weighing about $225 \mathrm{~kg}$ were esophageally fistulated. The steers were put on the study pastures 10 days before collecting samples in each season. After dietary samples were collected, steers were removed from the pastures and placed in drylot until the next sampling period.

Samples were collected for 6 days in each of the following months: May, August, and December 1988 and March 1989. Collections were made for 3 consecutive days from the rotation pasture where cows were grazing and for 3 consecutive days from the continuous yearlong pasture where another herd of cows were grazing. Steers were allowed from 1 to 5 days to adapt to the next pasture before sampling was again initiated. The sampling scheme involved taking esophageal samples and counting bites each collection day. Fecal samples were always collected 24 hours later. Procedures for collecting fistula samples involved penning the animals in late afternoon until initiation of collection the following morning at 0700 hours. Overnight fasting helps prevent regurgitation of rumen contents when sampling the following morning, but may cause the animals to be less selective (Holechek et al. 1984). However, as reported by Coates et al. (1987) and observed in this study, the steers did not appear to be less selective or eat faster compared to observations at other times. Before grazing, the stainless steel cannulas were removed from each steer and canvas bags with screen bottoms were placed on each animal for collecting samples. Steers were driven to an area near where the cows were grazing and allowed to graze for 30 minutes. Collection bags were then removed and the cannulae replaced. The bite count procedure consisted of a person following each steer, counting and recording each bite the steer ate during the 30 minutes of esophageal sampling. The observer stayed close to the steer, generally less than $3 \mathrm{~m}$, in order to recognize plants being eaten.

After esophageal and bite count sampling was completed each morning, steers were released to graze freely until being penned that evening. Samples of the esophageal extrusion from each steer were immediately placed on ice for transportation to the laboratory where it was dried, stored and ground for later botanical analysis. Fresh fecal samples were collected from each steer as soon as they were observed defecating early in the morning (days 2 thru 7) before they started to graze. Fecal samples were treated the same as the esophageal samples.

\section{Botanical Analyses}

Microscopic slide preparation and analysis were the same for esophageal fistula and fecal material. Five slides were prepared from each fecal and esophageal fistula sample. Sample material was soaked in sodium hydroxide and mounted using techniques described by Holechek (1982). The slides were dried at room temperature for 3 to 4 weeks before analysis. Slides of reference plant species collected from the study area were prepared in the same manner as those for the fecal and fistula material. These ref- 
erence slides were used to aid in correctly identifying the plant fragments contained in the esophageal fistula and fecal material. The observer practiced on slides prepared with known mixtures of plants from the study site as described by Holechek and Gross (1982). Twenty fields were systematically observed at $125 \mathrm{x}$ magnification for a total of 100 fields/sample. Plant fragments were identified by epidermal characteristics and recorded as frequencies. Relative frequency of each species in the diet of each steer for each day was calculated and this was converted to relative density (Fracker and Brischle 1944) to obtain an estimate of the weight of each plant species in the diet.

Number of bites of each plant species was divided by total number of bites of all species and a percentage that each species comprised of the diet was obtained. Number of bites were considered proportional to the intake weight of a species as suggested by Regelin et al. (1974), and were not adjusted for bite size as suggested by Free et al. (1971).

\section{Herbage Available}

Herbage available (kg/ha) was measured in the same locations where steers grazed during collection periods. Ten $0.5 \times 1.0 \mathrm{~m}$ quadrats were clipped each day along a transect where the steers grazed each day. A total of 60 quadrats were clipped for each collection period. Current year's growth was clipped at ground level and separated from old growth. Samples were air dried and the weight of each species recorded.

Weight of mesquite leaves, longleaf ephedra green stems and soaptree yucca green leaves was determined by dimension analysis (Ludwig et al. 1975). Shrub weight available per unit area was determined by multiplying density of shrubs times average volume times average weight per volume. Density of shrubs was determined from thirty, $50 \times 4 \mathrm{~m}$ transects in each pasture in the areas where the steers grazed. The volume of each shrub occurring in the transects was determined by measuring the height and the long and short diameters. Mesquite volume was determined using the upper half prolate spheroid formula and the volume for the other shrubs was determined using a formula for a cylinder (Ludwig et al. 1975).

\section{Data Analyses}

Diet techniques were compared for major species and groups of species. Diets were compared in a mixed model factorial experiment in a completely randomized block design. Steer-day was the experimental unit. Observations within a season and grazing strategy were pooled across days for a total of 48 records. The main effects, steer (considered block), grazing strategy and season were tested using the steer $X$ grazing strategy $X$ season interaction as the testing term. Diet techniques and associated interactions were tested using the residual error term with 16 degrees of freedom. The loss of degrees of freedom by pooling across days within a season and grazing strategy allowed the sources of variation to be tested with more precise error terms (SAS 1985) in a general linear model. Least square means were used to calculate all probability values testing the hypothesis that the diets estimated by each technique were similar. Significant differences were noted where $\mathrm{P}<0.10$.

Diets determined by each technique were also compared with each other for each sampling period using Kulczynski's similarity index (Oosting 1956): $2 \mathrm{w} / \mathrm{a}+\mathrm{b} \times 100$, where $\mathrm{W}=$ is the total sum of the lowest of each pair of percentages common to the diets determined by 2 techniques; $a$ and $b$ represent the sum of all percentages found, respectively, in the a and b diets. The index may vary from $0 \%$ (no similarity) to $100 \%$ which indicates diets are identical.

For similarity indices mean and standard errors were calculated by season and grazing strategy. Individual species were also ranked as to their abundance in the mean diet determined by each technique across seasons and grazing strategies (Vavra et al. 1978). This importance value allows the comparison of which species were the overall important constituents in the diets.

\section{Results and Discussion}

The 3-way interaction, dietary technique $x$ grazing strategy $\times$ season was significant for 5 of the 8 common species and plant groups tested (Table 1). In each sampling period steers were hazed early in the morning to where the resident cows were grazing. The cows, being familiar with the pastures grazed on certain vegetation types in the different seasons. Therefore, the steers had differing amounts available of the common forage plants between pastures and among seasons. The differences in availability of forage plants (Table 2) were reflected in the diets selected. The higher amount of available forage in December was because the cows were grazing more in the grassland areas and because late summer and early fall rains caused an increase in forb growth.

Differences within a dietary technique between grazing strategies (Table 1) reflects the variation in the amount available of a particular species between locations where the resident cow herds were grazing in their respective pastures. For example, in May, black grama comprised $3 \%$ of the bite count diet on the yearlong pasture $(5 \mathrm{~kg} / \mathrm{ha}$ available) and $13 \%$ of the diet on the seasonal pastures (118 kg/ha available, Table 2$)$.

The 3 dietary techniques did not give similar estimates of the diets eaten by the steers. The method suggested by Regelin et al. (1974) of bites being equal and directly proportional to the weight of each species being consumed was not supported by this study. The handplucks they collected from forage specics to simulate deer's diets needed to be fairly uniform. Because of mouth size and style of eating, deer generally eat smaller and more uniform bites compared to steers. Steers can eat large amounts of forage rather indiscriminately, often eating more than 1 species and several plant parts in a bite. However, steers can also take small bites. For example, the amount of three-awns in the bite count diets was greater than the amounts determined by the other 2 techniques for 3 of the 4 sampling periods (Table 1). These differences are probably because the steers tended to take many small bites from around the base of the three-awns where there were more green leaves rather than a few large bites from the top where more seedheads and dead plant material were present. This same pattern can be seen in the May and March sampling period for the other-forbs category. In these seasons there were many forbs of small stature, and though many bites were recorded, they comprised little of the diet weight determined by the analysis of esophageal and fecal material. For croton an opposite pattern was found; the number of bites generally underestimated the amount of weight being consumed as compared to the other 2 techniques. This was because of crotons' larger stature and upright growth form which allowed the steers to often eat an entire plant in 1 bite. 
Table 1. Comparison of steer diets in 1988-1989 (\% relative weight averaged across 3 sampling days) using 3 techniques: bite count, microhistological examination of esophageal extrusa and microhistological examination of feces in 2 grazing strategies in the northern Chihuahuan Desert.

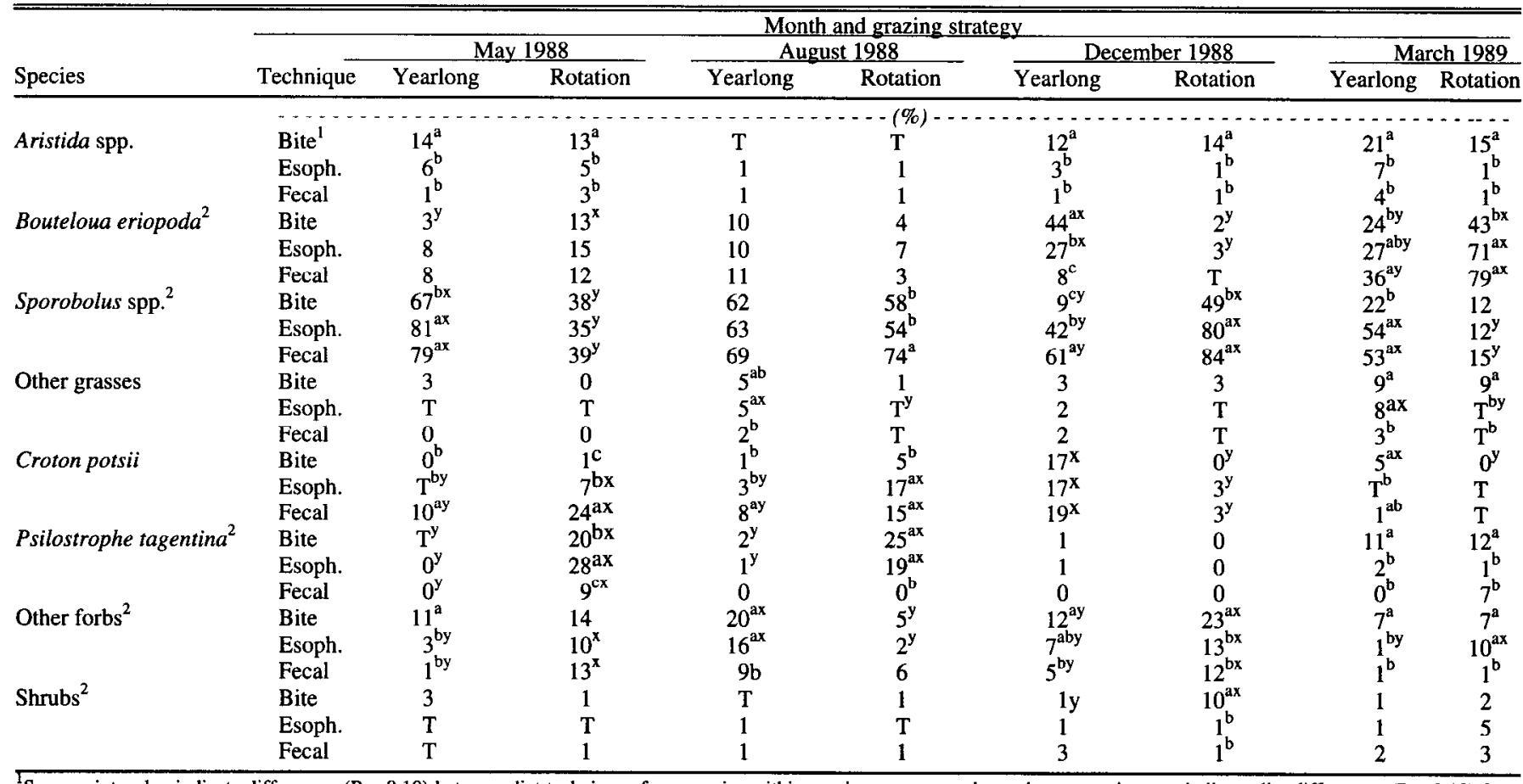

Superscripts a,b,c indicate differences $(\mathrm{P}<0.10)$ between diet techniques for a species within grazing strategy and month, superscripts $\mathrm{x}, \mathrm{y}$ indicate diet differences $(\mathrm{P}<0.10)$ for a \&pecies between grazing strategies within month.

Species or group of species had significant $(\mathrm{P}<0.10)$ dietary technique $\times$ grazing strategy $X$ season interaction.

Another difficulty with the bite count method was that of identifying individual species of plants in all growth stages at distances up to $3 \mathrm{~m}$. Theurer et al. (1976) and Bjugstad et al. (1970) reported that problems with the bite count method included plant species identification and determination of the quantity of a plant consumed. Some differences found when comparing bite count to the other techniques were probably due to individual observers over or underestimating the number of bites.

The bite count procedures does not require the use of esophageal fistulated animals but does require relatively gentle animals. Forbes and Beattie (1987) showed that biting rate was slower for fistulated animals than non-fistulated animals. More

Table 2. Availability (kg/ha) of herbage in 4 seasons (1988-1989) in yearlong and rotationally grazed pastures in the northern Chihuahuan Desert. Numbers are mean and mean standard error of 3 transects of 10 clipped plots each, $n=3$.

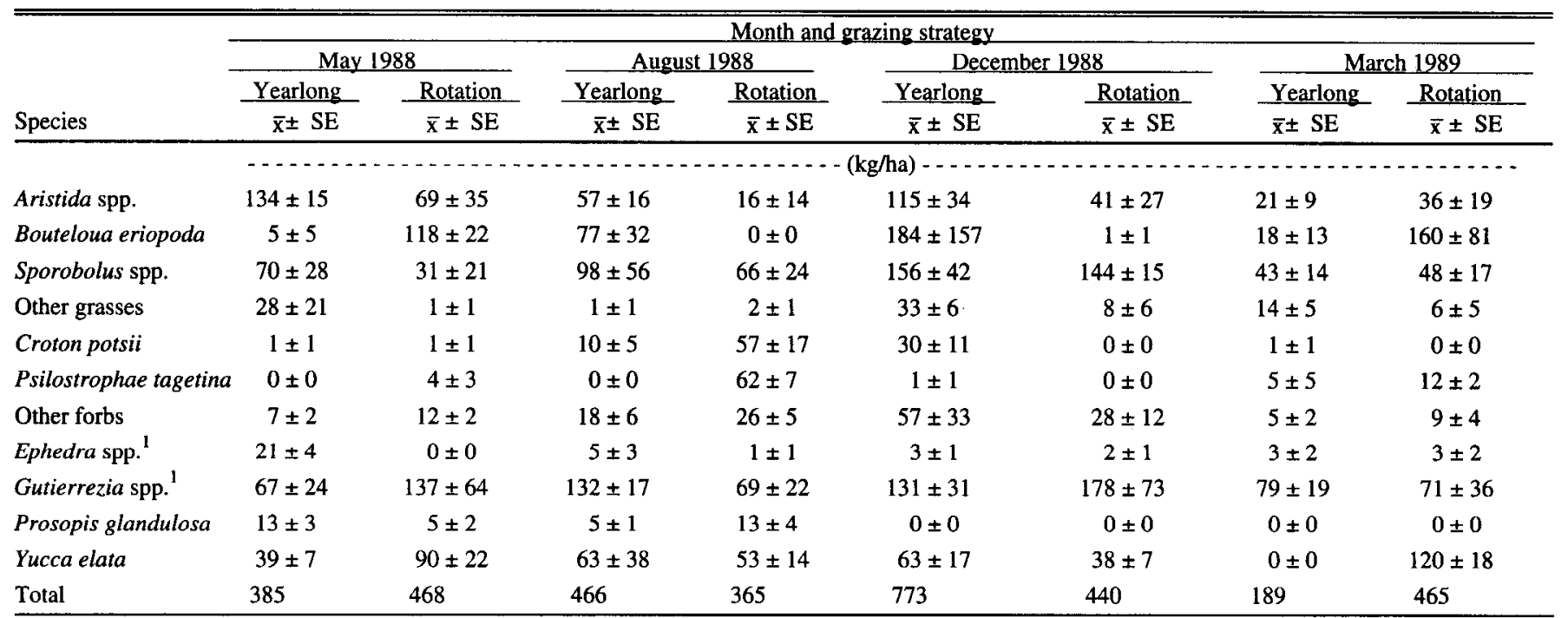

${ }^{1}$ Green leaves on Prosopis; green stems on Ephedra spp. 
Table 3. Kulczynski similarity indices (\%) comparing dietary techniques for steers grazing on continuously and rotationally grazed pastures in 4 seasons, 1988-1989.

\begin{tabular}{|c|c|c|c|c|c|c|c|c|c|c|}
\hline \multirow[b]{3}{*}{$\begin{array}{l}\text { Dietary } \\
\text { techniques }\end{array}$} & \multicolumn{10}{|c|}{ Month and grazing strategy ${ }^{\mathrm{T}}$} \\
\hline & \multicolumn{2}{|c|}{ May 1988} & \multicolumn{2}{|c|}{ Aug. 1988} & \multicolumn{2}{|c|}{ Dec. 1988} & \multicolumn{2}{|c|}{ Mar. 1989} & \multicolumn{2}{|c|}{ Mean } \\
\hline & $\begin{array}{l}\text { Yearlong } \\
\overline{\mathrm{x}} \pm \mathrm{SE}\end{array}$ & $\begin{array}{l}\text { Rot.. } \\
\overrightarrow{\mathrm{x}} \pm \mathrm{SF}\end{array}$ & $\begin{array}{l}\text { Yearlong } \\
\bar{x} \pm S F\end{array}$ & $\begin{array}{l}\text { Rot.. } \\
\overline{\mathrm{x}} \pm \mathrm{SF}\end{array}$ & $\begin{array}{l}\text { Yearlong } \\
\overline{\mathrm{x}} \pm \mathrm{SE}\end{array}$ & $\begin{array}{l}\text { Rot.. } \\
\overline{\mathrm{x}} \pm \mathrm{SE}\end{array}$ & $\begin{array}{c}\text { Yearlong } \\
\overline{\mathrm{x}} \pm \mathrm{SF}\end{array}$ & $\begin{array}{c}\text { Rot.. } \\
\overline{\mathrm{x}} \pm \mathrm{SE}\end{array}$ & $\begin{array}{c}\text { Yearlong } \\
\bar{x} \pm S E\end{array}$ & $\begin{array}{l}\text { Rot.. } \\
\bar{x} \pm \mathrm{SE}\end{array}$ \\
\hline $\begin{array}{l}\text { Bite count vs. } \\
\text { esophageal analysis }\end{array}$ & $80 \pm 52$ & $69 \pm 5$ & $77 \pm 3$ & $82 \pm 5$ & $62 \pm 5$ & $61 \pm 8$ & $55 \pm 7$ & $53 \pm 11$ & $69 \pm 3$ & $66 \pm 4$ \\
\hline $\begin{array}{l}\text { Esophageal analysis } \\
\text { vs. fecal analysis }\end{array}$ & $84 \pm 3$ & $67 \pm 5$ & $75 \pm 4$ & $68 \pm 3$ & $67 \pm 7$ & $91 \pm 2$ & $84 \pm 3$ & $75 \pm 8$ & $78 \pm 3$ & $75 \pm 3$ \\
\hline
\end{tabular}

${ }_{1}$ Yearlong = Continuous grazing; Rot. = Rotational grazing.

${ }^{2}$ Numbers are mean and mean standard error, $n=6$.

research is needed to evaluate the similarity of diets and bite rate between fistulated and non-fistulated animals.

The amount of time between when fecal samples and samples for the other 2 techniques were collected may not have allowed enough time for passage of food stuff. Voth and Black (1973) pointed out that a major limitation of fecal analysis is inaccuracy in assessment of actual diets when they include a high component of forbs, shrubs or both. Vavra et al. (1978), found differences between diets estimated from esophagal extrusa and fecal samples collected 24 hours later. Simao Neto et al. (1987), in studying the passage rate of seeds through ruminants, recovered the greatest amount of seed between 48 and 72 hours after ingestion. In this study, since samples for each steer were averaged across days, the mean time between fecal collection, and other dietary samples for comparison purposes was $\mathbf{4 0}$ hours. This length of time may have been too great for some forbs and plant parts that digest readily and it may have been too short of time for plants with low digestibility (Sanders et al. 1980, McInnis et al. 1983).

Esophageal fistula slides compared well with the reference slides, but fecal material which was partially digested was difficult to compare with undigested samples on the reference slides. Holechek and Valdez (1985) reported observers found more difficulty in identifying fragments in fecal material than undigested fragments from esophageal samples. In other instances plant fragments were present in feces, but were so transparent that cellular structure was not easily discernible. This observation was also noted by Ward (1970) and Sanders et al. (1980). Slater and Jones (1971) reported that some species may become unidentifiable in feces.

Another reason for differences among techniques was apparently because of the different lengths of the sampling periods. Ingesta collected from the esophagus was an actual portion of the diet for only a short time period (30 minutes) in a small area. Therefore, direct comparisons between what a stecr grazed for 24 hours (fecal sample) and what a steer grazed for only 30 minutes (esophageal and bite count samples) may not be a valid comparison.

Mean similarity indices between dietary techniques varied among seasons and between grazing strategies (Table 3). Generally the highest similarities were between the diets estimated by esophageal and fecal analysis (67\% to $91 \%$ ) while the lowest similarities were between bite count and fecal analysis (37\% to $75 \%$ ). The low similarities indicate the problems already discussed and that no single technique will give an adequate estimation of dietary composition or intake under all situations. Vavra et al. (1978), discussed the idea that it may not always be necessary for many management and research activities to have an exact estimate of amount of intake for each plant species. Rather they suggest ranking species by an "importance value" based on amount a species makes up of the diet. Ranking the species in the diets determined by the 3 techniques in this study shows little difference in the top 3 ranks among techniques (Table 4). The top 3 ranks of plants contribute nearly $68 \%$ to the diets averaged across the 4 seasons. The less common species are not as consistently ranked because they were not as evenly distributed across the study pastures as were the top ranked species.

Any of the 3 dietary techniques provides similar information regarding the importance of major plant species in grazing animals in the northern Chihuahuan Desert. However, the 3 techniques do not give the same estimate of weight intake for a plant species. To improve the estimate of intake for large ruminants using the bite count technique it is necessary to modify the bite count techniques as suggested by Reppert (1960) or Free et al. (1971). However, as Mohammad et al. (1995) suggests, fecal analysis may be the most appropriate for most situations. The technique a person chooses to use should depend on resources available, how the data will be used, and the expertise of the observers.

Table 4. Importance rank of forage components based on abundance in diets of steers determined by 3 techniques averaged across sampling date and grazing strategy.

\begin{tabular}{llll}
\hline \multirow{2}{*}{$\begin{array}{l}\text { Importance } \\
\text { rank }\end{array}$} & Bite count & $\begin{array}{c}\text { Esophageal } \\
\text { analysis }\end{array}$ & $\begin{array}{l}\text { Fecal } \\
\text { analysis }\end{array}$ \\
\hline 1 & Sporbolus & Sporobolus & Sporbolus \\
2 & Bouteloua & Bouteloua & Bouteloua \\
3 & Other forbs & Other forbs & Croton \\
4 & Aristida & Psilostrophe & Other forbs \\
5 & Psilostrophe & Croton & Aristida \\
6 & Other grass & Aristida & Shrub \\
7 & Croton & Other grass & Other grass \\
8 & Shrub & Shrub & Psilostrophe \\
\hline
\end{tabular}




\section{Literature Cited}

Beck, R.F. 1978. A grazing system for semiarid lands. p. 569-572. In: D. N. Hyder (ed.) Proc. 1st Int. Rangeland Congr. Soc. Range Manage. Denver, Colo.

Bjugstad, A.J., H.S. Crawford, and D.L. Neal. 1970. Determining forage consumption by direct observation of domestic animals. $p$. 101-104. In: H. A. Paulsen and E. H. Reid (ed.), Range and Wildl. Habitat Evaluation. USDA Forest Service Misc. Pub. No. 1147.

Coates, D.B., P. Schachemmann, and R.J. Jones. 1987. Reliability of extrusa samples collected from steers fistulated at the oesophagus to estimate the diet of resident animals in grazing experiments. Australian J. Exp. Agr. 27:739-745.

Forbes, T.D.A. and M.M. Beattie. 1987. Comparative studies of ingestive behavior and diet composition in esophageal-fistulated and nonfistulated cows and sheep. Grass and Forage Sci. 42:79-84.

Fracker, S.B. and J.A. Brischle. 1944. Measuring the local distribution of Ribes. Ecol. 525:283-303.

Free, J.C., P.L. Sims, and R.M. Hansen. 1971. Methods of estimating dry-weight composition in diets of herbivores. J. Anim. Sci. 32:1003-1008.

Galt, H.D., B. Theurer, J.H. Ehrenreich, W.H. Hale, and S.C. Martin. 1969. Botanical composition of diet of steers grazing a desert grassland range. J. Range Manage. 22:14-19.

Holechek, J.L. 1982. Sample preparation techniques for microhistological analysis. J. Range Manage. 35:267-268.

Holechek, J.L. and B.D. Gross. 1982. Training needed for quantifying simulated diets from fragmented range plants. J. Range Manage. 36:644-647.

Holechek, J.L. and R. Valdez. 1985. Magnification and shrub stemmy material influences on fecal analysis accuracy. J. Range Manage. 38:350-352.

Holechek, J.L., M. Vavra, and R.D. Pieper. 1984. Methods for determining the botanical composition, similarity, and over lap of range herbivore diets. p. 425-471. In: Developing Strategies for Rangeland Management. National Res. Counc., National Academy of Sciences. Westveiw Press, Boulder, Colo.
Ludwig, J.A., J.F. Reynolds, and P.D. Whitson. 1975. Size biomass relationships of several Chihuahuan Desert shrubs. Amer. Midland Natur. 94:451-461.

McInnis, M.L., M. Vavra, and W.C. Krueger. 1983. A comparison of four methods used to determine the diets of larger herbivores. J. Range Manage. 36:302-307.

Mohammad, A.G., R.D. Pieper, J.D. Wallace, J.L. Holechek, and L.W. Murray. 1995. Comparison of fecal analysis and rumen evacuation techniques for sampling diet botanical composition of grazing cattle. J. Range Manage. 48:202-205.

Oosting, H.J. 1956. The study of plant communities. 2nd Ed. W.H. Freeman and Co., San Francisco, Calif.

Regelin, W.L., O.C. Wallmo, J. Nagy, and D.R. Dietz. 1974. Effect of logging on forage values for deer in Colorado. J. Forest. 72:282-285.

Reppert, J.N. 1960. Forage preference and grazing habits of cattle at the Eastern Colorado Range Station. J. Range Manage. 13:58-62.

SAS. 1985. SAS User's Guide: Statistics, Fifth Ed. SAS Inst. Inc. Cary, N.C.

Sanders, K.D., B.E. Dahl, and G. Scott. 1980. Bite count vs. fecal analysis for range animals diet. J. Range Manage. 32:146-149.

Simao Neto, M., R.M. Jones, and D. Ratcliff. 1987. Recovery of pasture seed ingested by ruminants 1 . Seed of six tropical pasture species fed to cattle, sheep, and goats. Australian J. Exp. Agr. 27:239-246.

Slater, J. and R. Jones. 1971. Estimation of the diets selected by grazing animals from microscopic analysis of faeces-A warning. J. Australian Inst. Agr. Sci. 37:238-240.

Theurer, C.B., A.L. Lesperance, and J.D. Wallace. 1976. Botanical composition of the diet of livestock grazing native range. Ariz. Agr. Exp. Sta. Bull. 233

Vavra, M., R.W. Rice, and R.M. Hansen. 1978. A comparison of esophageal fistula and fecal material to determine steer diets. J. Range Manage. 31:11-13.

Voth, E.H. and H.C. Black. 1973. A histological technique for determining feeding habits of small herbivores. J. Wildl. Manage. 37:223-231.

Ward, A.L. 1970. Stomach content and fecal analysis: Methods of forage identification. p. 146-158. In: H.A. Paulsen and E.H. Reid (ed.), Range and Wildlife Habitat Evaluation. USDA Forest Service Misc. Pub. No. 1147. 